\title{
Investigation of Dioxin/Furans, PAHs and Heavy Metals in Sarcheshmeh Copper Complex Soil, Iran
}

\author{
Mohammad Aminzadeh Gohari', Reihaneh Roshanak ${ }^{2 *}$, Saman Khabazi ${ }^{2}$, Hossein Ali Hakimi ${ }^{1}$ \\ ${ }^{1}$ National Iranian Copper Industries Company, Sarcheshmeh Copper Complex, Office of HSE, Kerman, Iran \\ ${ }^{2}$ Sabzandishane Zamine Asre Sanat Environmental Company, Isfahan, Iran \\ Email: ${ }^{*}$ roshanak.reihaneh@yahoo.com
}

How to cite this paper: Gohari, M.A., Roshanak, R., Khabazi, S. and Hakimi, H.A. (2017) Investigation of Dioxin/Furans, PAHs and Heavy Metals in Sarcheshmeh Copper Complex Soil, Iran. Journal of Geoscience and Environment Protection, 5, 121-136. https://doi.org/10.4236/gep.2017.58011

Received: April 10, 2017

Accepted: July 31, 2017

Published: August 3, 2017

Copyright $\odot 2017$ by authors and Scientific Research Publishing Inc. This work is licensed under the Creative Commons Attribution International License (CC BY 4.0). http://creativecommons.org/licenses/by/4.0/

\begin{abstract}
Surface soil samples were collected from Sarcheshmeh Copper Smelter Plant and analyzed for 16 Polycyclic Aromatic Hydrocarbons (PAHs), polychlorinated dibenzo-p-dioxin/furans ( $\mathrm{PCDD} / \mathrm{Fs}$ ), and heavy metals to determine their concentrations, distributions, and probable sources of contamination. The mean concentrations of $\Sigma \mathrm{PAHs}, \mathrm{As}, \mathrm{Pb}, \mathrm{Zn}, \mathrm{Se}, \mathrm{Cd}$, and $\mathrm{Cr}$ in the soil samples were 878.8, 850, 2185, 2455, 21, and $24 \mathrm{mg} / \mathrm{kg}$, respectively. Besides, their Toxic Equivalents (TEQs) were calculated. The samples generally displayed elevated concentrations of heavy metals when finding the toxic values of dioxin/furan compounds in comparison to the limit values for industrial uses. The background concentrations, molecular indices, and ring classes of the heavy metals indicated that their sources and those of PAHs were both geogenic and pyrolitic. The mean concentrations of total PAHs, PCDD/Fs, and heavy metals were compared with the reports from industrial areas throughout the world and the contamination rates at Sarcheshmeh Copper Plant were found to be moderate.
\end{abstract}

\section{Keywords}

Dioxin, PAHs, Heavy Metals, Soil, Copper Smelter Plant

\section{Introduction}

Huge areas of waste lands contaminated by persistent organic pollutants have been left due to the past industrial activities, such as coal exploitation by coking plants or steel smelting industries. The related pollutants include Polycyclic Aromatic Hydrocarbons (PAHs), organic compounds, heavy metals, and polychlorinated dibenzo-p-dioxins and dibenzofurans (PCDD/PCDFs). A group of 
inorganic chemical hazards most commonly found at contaminated sites are heavy metals, such as zinc $(\mathrm{Zn})$, arsenic (As), cadmium $(\mathrm{Cd})$, copper $(\mathrm{Cu})$, chromium $(\mathrm{Cr})$, nickel $(\mathrm{Ni})$, mercury $(\mathrm{Hg})$, and lead $(\mathrm{Pb})$ [1]. Many metals like those mentioned above as well as metalloids are released into the soil during the smelting of metalliferous ores [2]. Due to their toxicities and bioaccumulative properties, Persistent Organic Pollutants (POPs), such as PCDD/PCDFs and polybrominated diphenyl ethers (PBDEs), are considered to be important. Various geogenic, biogenic, and anthropogenic origins have been ascribed to the toxic organic compounds in the environment [3]. The burnt and unburnt petroleum products originating from machines and exhausts of vehicles mainly produce seriously threatening effluents to humans and aquatic and terrestrial organisms by polluting sediments and topsoil, as well as surface and ground water [4]. Soil is an essential reservoir for organic pollutants [5]. PCDD/Fs are the unwanted by-products formed by many combustion processes and industrial activities [6]. Dioxin-like toxicities are found in only 7 and 10 out of 75 and 135 possible PCDD and PCDF congeners, respectively, especially those with chlorine substitutions in the 2, 3, 7, 8-positions. Similarly, only 12 out of 209 possible PCB congeners show dioxin-like toxicities [7]. Arranged in different structural configurations, PAHs are a large group of chemicals with two or more fused aromatic rings [8]. They are the unintentional by-products widely spread in the whole environment, including air, water, soil, and sediments [9] [10] [11]. Their high mobility in the environment is due to their physicochemical properties to let them ubiquitously distribute across air, soil, and water bodies [12] [13] [14]. Several PAHs are carcinogenic like benzo[a]-anthracene $(\mathrm{BaA})$ and benzo[a]pyrene $(\mathrm{BaP})$ and some are precursors to carcinogens, such as benzo[b]fluoranthene (BbF) [15] [16]. As reported by Kameda and Yu [17] [18], ordinary residents are potentially threatened via exposures to PAHs, resulting in several health-related problems like eye, mucous membrane, and skin irritations, reduced bone marrow function, weakened nervous system, and various cancer types [4] [19] [20]. Different pyrolytic, petrogenic, and diagenetic origins have been identified for PAHs, which include incomplete combustion of organic matters, natural oil leakage and spillage of petroleum products from petrochemical plants, and natural precursors and transformations during early stages, respectively [21]-[26]. The objectives of this study were to determine the concentrations of PAHs, dioxin, furans, and heavy metals in topsoil at Sarcheshmeh Copper Plant and identify the possible sources of these pollutants.

\section{Materials and Methods}

Sarcheshmeh ore body situated $160 \mathrm{~km}$ southwest of Kerman City in Kerman Province is the largest porphyry copper deposit in Iran occurring at the so-called "Central Iranian Volcanic Belt (CIVB)" together with a number of other porphyry copper deposits [27] [28] [29]. The investigated soil samples were excavated at Sarcheshmeh copper complex in 2016. This complex contains copper mine, smelter, and refinery plants. In this study, the topsoil collected from the 
plant surrounding was divided into 20 stations for PAH, 20 stations for heavy metals, and 5 stations for dioxins/furans (Table 1) (Figure 1).

To determine heavy metals, the samples were diluted to appropriate volumes and analyzed for $\mathrm{Pb}, \mathrm{Se}, \mathrm{Cr}, \mathrm{Mn}, \mathrm{Fe}, \mathrm{As}, \mathrm{Cu}, \mathrm{Pt}, \mathrm{Cd}$, and $\mathrm{Zn}$ ions using Atomic Absorption Spectrometry (AAS). After washing PAH and PCDD/F containers with n-hexane and drying them in an oven at $180^{\circ} \mathrm{C}$ for $3 \mathrm{~h}$, the samples were homogenized in the gas-tight seals made from aluminum-foiled screw caps, stored in pre-cleaned glass jars, and frozen in a cool box at $4^{\circ} \mathrm{C}$ to be then transported to the laboratory. PCDD/F samples were extracted, chromatographically cleaned up, and quantified based on the current European Standard Protocols [30] and finally analyzed with toluene through High-Resolution Gas Chromatography/High-Resolution Mass Spectrometry (HRGC/HRMS) in a certified laboratory (Dr. Wessling Laboratory, Germany) following $48 \mathrm{~h}$ of extraction.

Table 1. Description of the sampling sites in Sarcheshmeh copper plant.

\begin{tabular}{|c|c|c|c|c|c|}
\hline \multirow[t]{2}{*}{ Sampling site } & \multicolumn{2}{|c|}{ UTM (N40) } & \multicolumn{3}{|c|}{ Sample code } \\
\hline & $\mathrm{X}$ & $\mathrm{Y}$ & $\mathrm{PCDD} / \mathrm{f}$ & Heavy metal & PAHs \\
\hline Inside the smelter plant & 389,510 & $3,317,334$ & $\mathrm{D}-1$ & & \\
\hline NE molybdenum thickeners & 389,728 & $3,317,151$ & $\mathrm{D}-2$ & & \\
\hline Western the Refinery and Casting unit & 389,296 & $3,317,690$ & D-3 & & \\
\hline Stack & 389,399 & $3,317,397$ & $\mathrm{D}-4$ & & \\
\hline NE smelter plant & 389,698 & $3,317,526$ & D-5 & & \\
\hline SW smelter plant & 389,598 & $3,317,280$ & & S-H-1 & S-1 \\
\hline Inside the smelter plant & 389,511 & $3,317,320$ & & $\mathrm{~S}-\mathrm{H}-2$ & S-2 \\
\hline Inside the smelter plant & 389,458 & $3,317,327$ & & $\mathrm{~S}-\mathrm{H}-3$ & S-3 \\
\hline North of molybdenum thickeners & 389,633 & $3,317,173$ & & S-H-4 & S-4 \\
\hline NE smelter plant & 389,682 & $3,317,478$ & & S-H-5 & S-5 \\
\hline Stack & 389,434 & $3,317,407$ & & S-H-6 & S-6 \\
\hline NE Refinery and Casting unit & 389,557 & $3,317,686$ & & $\mathrm{~S}-\mathrm{H}-7$ & S-7 \\
\hline NW Refinery and Casting unit & 389,219 & $3,317,723$ & & $\mathrm{~S}-\mathrm{H}-8$ & S-8 \\
\hline Eastern the Gas power plant & 389,010 & $3,317,640$ & & S-H-9 & S-9 \\
\hline South of Sentry station & 389,906 & $3,317,732$ & & S-H-10 & S-10 \\
\hline North of HSE unit & 389,909 & $3,317,455$ & & S-H-11 & S-11 \\
\hline Eastern the Milk of lime plant & 389,913 & $3,317,168$ & & S-H-12 & S-12 \\
\hline SE main storage building & 389,913 & $3,316,635$ & & S-H-13 & S-13 \\
\hline Coarse ore storage & 389,598 & $3,316,458$ & & S-H-14 & S-14 \\
\hline South of Chemical storage & 390,147 & $3,316,809$ & & S-H-15 & S-15 \\
\hline Center of Chemical storage & 390,389 & $3,317,080$ & & S-H-16 & S-16 \\
\hline North of Chemical storage & 390,610 & $3,317,428$ & & S-H-17 & S-17 \\
\hline West of Environmental unit & 389,811 & $3,318,070$ & & S-H-18 & S-18 \\
\hline NW of Integrated Water Master plan & 390,290 & $3,317,926$ & & S-H-19 & S-19 \\
\hline Shaghayegh Rest house (Background sample) & 387,869 & $3,317,518$ & & S-H-20 & S-20 \\
\hline
\end{tabular}




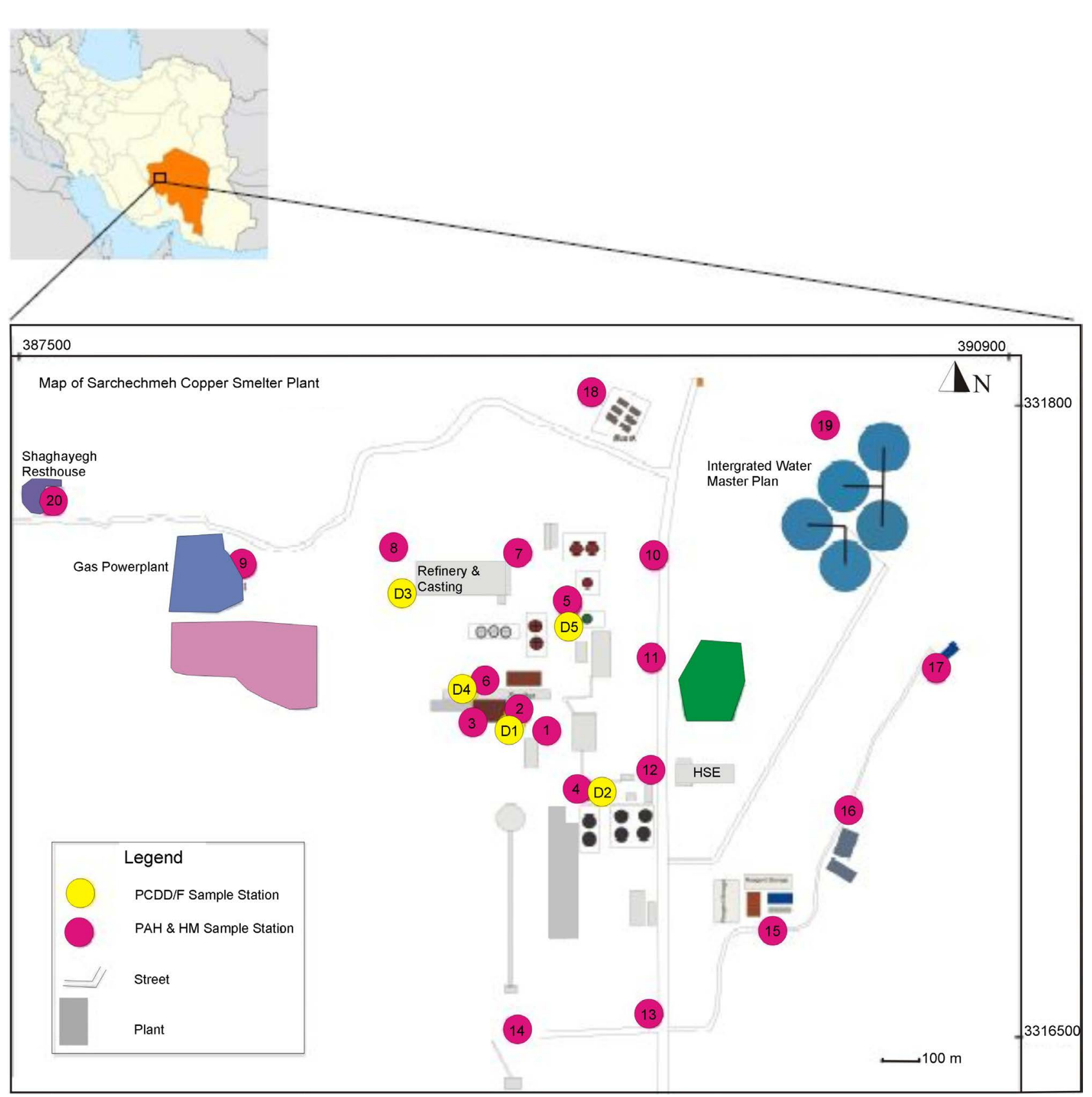

Figure 1. Locations of the sampling stations.

The recovery ratios of the samples spiked with a 13C12-labeled internal standard mixture of 2, 3, 7, 8-substituted PCDD/F were reported to range from $75 \%$ to 90\%. Using the International Toxicity Equivalency Factors (I-TEFs), 2, 3, 7, 8-TCDD equivalents (TEQs) in the sediments were calculated. The soil samples were analyzed for the $16 \mathrm{PAHs}$ (benzo[a]pyrene $(\mathrm{BaP})$, fluorene (Flu), pyrene (Pyr), benzo[a]anthracene (BaA), acenaphthene (Ace), phenanthrene (Phe), chrysene (Chr), anthracene (Ant), fluoranthene (Flu), acenaphthylene (Acy), benzo[b]fluoranthene $(\mathrm{BbF})$, benzo[k]fluoranthene $(\mathrm{BkF})$, naphthalene (Nap), benzo[ghi]perylene(BghiP), indeno [1, 2, 3-cd] pyrene (IP), and dibenz[a, h]anthraxcene (DahA)), generally which were determined in the environmental researches 
by using Gas Chromatography/Mass Spectrometry (GC/MS) (Agilent 6890NGC, 5975C Mass Selective Detector (MSD), USA) equipped with an HP-5MS capillary column $(30 \mathrm{~m} \times 0.32 \mathrm{~mm} \times 0.25 \mu \mathrm{m}$, Agilent, USA $)$ in the Selected IonMonitoring (SIM) mode (laboratory of Iran Mineral Processing Research Center). The flow rate of helium as a carrier gas was selected to be $1.5 \mathrm{~mL} / \mathrm{min}$. The initial temperature of the oven was set at $60^{\circ} \mathrm{C}(1$-min hold) and then raised to $295^{\circ} \mathrm{C}$ at a rate of $11^{\circ} \mathrm{C} / \mathrm{min}$ (5-min hold).

\section{Statistical Methods}

SPSS software was utilized to perform the statistical analyses. The minimums, maximums, and means of PAHs, PCDD/F, and heavy metals were calculated with the help of descriptive statistics. To reduce the dimensions of the multivariate problems, principal component analysis was applied. Moreover, measurements of the diagnostic ratios, such as Flu/(Flu + Pyr), Ant/(Ant + Phe), and $\mathrm{BaA} /(\mathrm{BaA}+\mathrm{Chr})$ were done to detect the sources of the PAHs.

\section{Results and Discussion}

\subsection{Dioxin Concentrations in the Soils}

The concentrations of PCDD/F in the soil samples were determined by using isotopic dilution, High-Resolution Gas Chromatography (HRGC) and HighResolution Mass Spectrometry (HRMS). Toxic Equivalency Factor (TEF) is defined as the carcinogenic capabilities of individual PCDD/Fs relative to 2, 3, 7, 8 -TCDD. The Toxic equivalents (TEQs) were calculated by the following equation:

$$
\mathrm{TEQ}=\Sigma \mathrm{Cn} \times \mathrm{TEFn}
$$

where $\mathrm{Cn}$ is each $\mathrm{PCDD} / \mathrm{F}$ concentration in the sample and TEFn is TEF for that $\mathrm{PCDD} / \mathrm{F}$ [31]. The total dioxin concentrations of the congeners of 2, 3, 7, 8-PCDD/Fs in Sarcheshmeh Copper Plant were converted into WHO-TEQ based on TEFs, which are presented in Table 2. Maximum PCDD/F TEQ in the samples of Sarcheshmeh Copper Plant was calculated to be related to D4 (26.9 $\mathrm{ng} / \mathrm{kg}$ ). The greater OCDD and 1, 2, 3, 4, 6, 7, 8-HpCDD concentrations for the 17 isomers of PCDD/F samples at Sarcheshmeh Copper Plant stations (Figure 2) were found in dioxins with the mean percentages of $75 \%$ and $18 \%$, respectively. Also, higher levels of OCDF (38\%), 1, 2, 3, 4, 6, 7, 8-HpCDF (21\%) and 1, 2, 3, 7, $8,9-\mathrm{HxCDF}(5 \%)$ were discovered in furans. The concentrations of the 17 isomers of PCDD/F in the soils of Sarcheshmeh Copper Plant were lower than the standard values of industrial soil in European countries. The limited levels of PCDD/F TEQ for industrial areas are 10 and $100 \mathrm{ng} \cdot \mathrm{kg}^{-1}$ in Czech Republic and Italy, respectively (Table 2).

Dioxins and furans compounds are the by-products of industrial, chemical and combustion processes. In general, dioxin is formed during industrial processes when chlorine is burned alone or in combination with organic materials. PVC, rubber, and plastics have been introduced for the manufacture of 
Table 2. Descriptive statistics of PCDD/F in the soil of Sarcheshmeh copper plant (ng.kg-1).

\begin{tabular}{|c|c|c|c|c|}
\hline Compounds & TEF & Mean & Min & Max \\
\hline $2,3,7,8$-TCDD & 1 & 0.37 & $<1$ & 1.85 \\
\hline $1,2,3,7,8-\mathrm{PeCDD}$ & 1 & 1.154 & $<2$ & 5.77 \\
\hline $1,2,3,4,7,8-\mathrm{HxCDD}$ & 0.1 & 1.716 & $<3$ & 8.58 \\
\hline $1,2,3,6,7,8-\mathrm{HxCDD}$ & 0.1 & 2.22 & $<3$ & 11.1 \\
\hline $1,2,3,7,8,9-\mathrm{HxCDD}$ & 0.1 & 2.6 & $<3$ & 13 \\
\hline $1,2,3,4,6,7,8-\mathrm{HpCDD}$ & 0.01 & 43.8 & $<15$ & 219 \\
\hline OCDD & 0.0001 & 188.2 & $<50$ & 941 \\
\hline $2,3,7,8$-TCDF & 0.1 & 3.522 & $<2$ & 14.8 \\
\hline $1,2,3,7,8-\mathrm{PeCDF}$ & 0.05 & 1.876 & $<2$ & 9.38 \\
\hline $2,3,4,7,8$-PeCDF & 0.5 & 4.44 & $<2$ & 18.6 \\
\hline $1,2,3,4,7,8-\mathrm{HxCDF}$ & 0.1 & 4.762 & $<3$ & 18.1 \\
\hline $1,2,3,6,7,8-\mathrm{HxCDF}$ & 0.1 & 4.03 & $<3$ & 15.4 \\
\hline $1,2,3,7,8,9-\mathrm{HxCDF}$ & 0.1 & 5.552 & $<3$ & 21.5 \\
\hline $2,3,4,6,7,8-\mathrm{HxCDF}$ & 0.1 & 0.6 & $<3$ & 3 \\
\hline $1,2,3,4,6,7,8-\mathrm{HpCDF}$ & 0.01 & 19.3 & $<15$ & 71.1 \\
\hline $1,2,3,4,7,8,9-\mathrm{HpCDF}$ & 0.01 & 3 & $<15$ & 15 \\
\hline OCDF & 0.0001 & 10.98 & $<50$ & 54.9 \\
\hline TEQ (excl) & & 6.03 & 0.0 & 26.9 \\
\hline Czech Republic Standard for TEQ & & 10 & & \\
\hline Italy standard for TEQ & & 100 & & \\
\hline
\end{tabular}

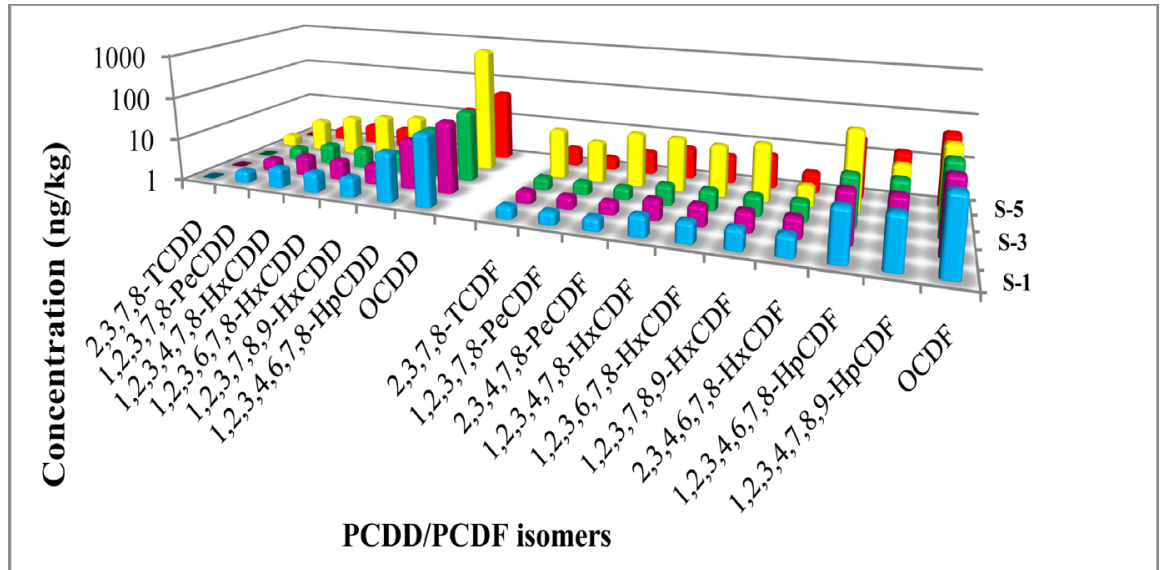

Figure 2. 3-dimensional graph of 17 dangerous isomers of dioxins and furans in Sarcheshmeh copper plant.

dioxins and furans as the important sources of chlorine [32]. Dioxin can be originated from combustion sources like burning wood, metal smelting furnace, cement kilns, hazardous waste incinerators, and vehicles burning leaded gasoline. Due to the presence of metals in Sarcheshmeh Copper Smelter Plant, there is a possible production of dioxin and furan sources in this plant; however, sam- 
ple analysis showed that only two samples contained dioxin compounds.

\subsection{Heavy Metal Concentrations in the Soils}

Heavy metals derived from trace pedogenetic processes for weathering soil parent materials naturally exist in the soil environment at the levels regarded as trace levels $\left(<1000 \cdot \mathrm{mg} \cdot \mathrm{kg}^{-1}\right)$, thus being rarely toxic [33] [34]. Soils may become contaminated by the accumulation of heavy metals. Due to the disturbance and acceleration of the naturally slow occurrence of geochemical cycle of metals by man, one or more heavy metals may be accumulated in most soils of rural and urban environments above the defined background values that can be high enough to ecosystems, plants, threaten human health, animals, or other media [35]. Substantial differences in $\mathrm{Zn}, \mathrm{Pb}, \mathrm{Cu}, \mathrm{As}$, Se, Cr, Mn, Pt, Fe, and $\mathrm{Cd}$ concentrations were observed in the soil samples of Sarcheshmeh copper Smelter plant (Table 3). The mean concentrations of As, Mn, Pb, Zn, Se, $\mathrm{Pt}, \mathrm{Cd}, \mathrm{Cr}, \mathrm{Fe}$, and $\mathrm{Cu}$ in the mentioned soil samples were $850,750,2185$, $2455,21,84,24$, and $92 \mathrm{mg} / \mathrm{kg}, 10.6 \%$, and $14.5 \%$, respectively. These values are higher than the background concentrations of the world soils and the limit values for industrial uses in Belgium. Kerman and Yazd provinces in Iran are known as mining areas. There are many active mines in these two provinces, such as Sarcheshmeh $(\mathrm{Cu})$, Darrehzar $(\mathrm{Cu})$, Meiduk $(\mathrm{Cu})$, Bafgh $(\mathrm{Fe})$, and Chadormalu $(\mathrm{Fe})$. Therefore, the soils of these parts of the country contain precious metals like copper, gold, molybdenum, and iron [36] [37] [38]. In this research, sample S-H-20 was taken from the distance of $2 \mathrm{~km}$ to the West of Sarcheshmeh Copper Plant as a background sample that represented high concentrations of heavy metals. As a result, the amounts of heavy metals in Sarcheshmeh soil can be considered to be high throughout the region, while the activities in the copper smelter plant have further intensified their amounts in the soil.

Table 3. Descriptive statistics of heavy metals in the soil of Sarcheshmeh copper plant $\left(\mathrm{mg} \cdot \mathrm{kg}^{-1}\right)$.

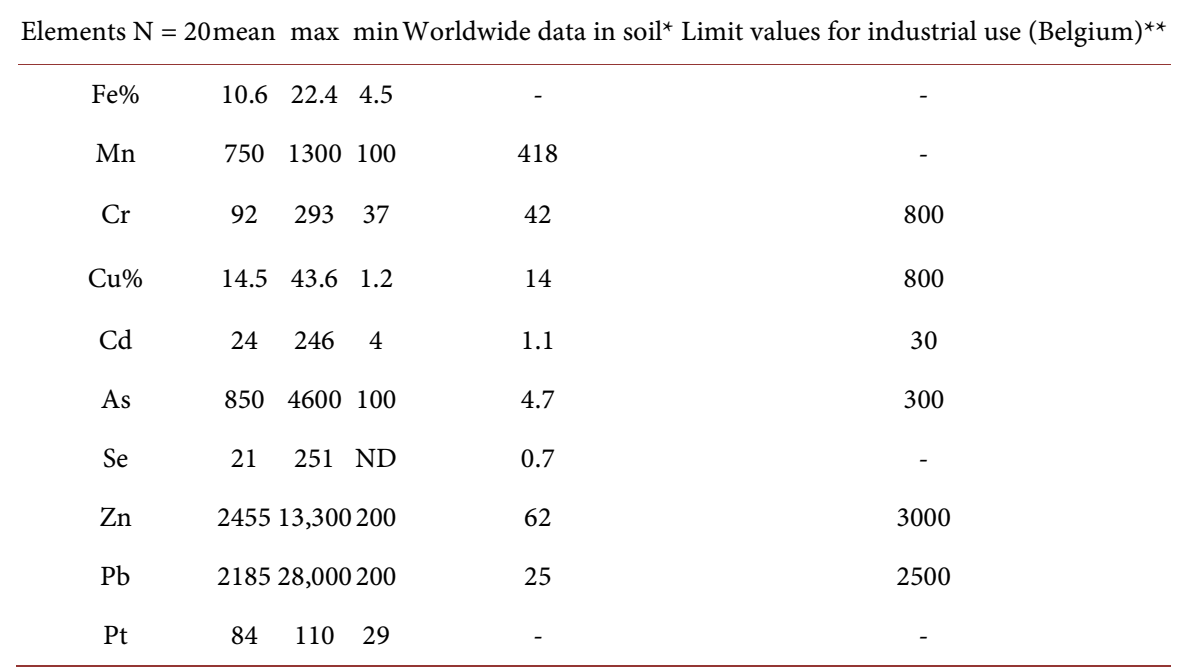

$*[39], * *[40]$. 


\subsection{Concentrations of PAHs in the Soils}

A Toxic Equivalency Factor (TEF) is defined as the individual Polycyclic Aromatic Hydrocarbon (PAH) carcinogenic potency relative to benzo[a]pyrene $(\mathrm{BaP})$. Toxic Equivalent (TEQ) concentration is calculated via the following formula:

$$
\mathrm{TEQ}=\Sigma \mathrm{Cn} \times \mathrm{TEFn}
$$

where $\mathrm{Cn}$ and TEFn represent PAH concentrations in the sample and TEF for those PAHs, respectively [20]. The statistically analyzed data are presented in Table 4. The total concentrations of $\Sigma \mathrm{PAHs}$ in the soil samples ranged from 0.32 to 4461.91. Also, the concentrations of $\Sigma$ carcinogenic PAHs (Np, BaA, Chr, $\mathrm{BbF}, \mathrm{BkF}, \mathrm{BaP}, \mathrm{DahA}$, and IP) and $\Sigma$ non-carcinogenic PAHs (Acy, Ace, Fl, Phe,

Table 4. Descriptive statistics of PAHs in the soil of Sarcheshmeh copper plant $\left(\mu \mathrm{g} \cdot \mathrm{kg}^{-1}\right)$.

\begin{tabular}{|c|c|c|c|c|c|c|}
\hline $\begin{array}{c}\text { Compounds } \\
\mathrm{N}=20\end{array}$ & Aromatic Rings & TEF & $\begin{array}{l}\text { Agents Classified } \\
\text { by the IARC }\end{array}$ & mean & $\min$ & $\max$ \\
\hline Naphthalene (Np) & 2 & 0.001 & $2 \mathrm{~B}$ & 13.11 & 0.02 & 53.02 \\
\hline Acenaphthylene (Acy) & 3 & 0.001 & 3 & 20.84 & 0.02 & 278.82 \\
\hline Acenaphthene (Ace) & 3 & 0.001 & 3 & 17.82 & 0.02 & 187.99 \\
\hline Fluorene (Fl) & 3 & 0.001 & 3 & 40.18 & 0.02 & 441.71 \\
\hline Phenanthrene (Phe) & 3 & 0.001 & 3 & 81.71 & 0.02 & 392.60 \\
\hline Anthracene (Ant) & 3 & 0.01 & 3 & 20.21 & 0.02 & 190.00 \\
\hline Fluoranthene (Flu) & 4 & 0.001 & 3 & 224.25 & 0.02 & 908.56 \\
\hline Pyrene (Pyr) & 4 & 0.001 & 3 & 342.43 & 0.02 & 1789.21 \\
\hline Benzo[a]anthracene $(\mathrm{BaA})$ & 4 & 0.1 & $2 \mathrm{~B}$ & 18.72 & 0.02 & 69.00 \\
\hline Chrysene (Chr) & 4 & 0.01 & $2 \mathrm{~B}$ & 43.71 & 0.02 & 190.00 \\
\hline Benzo[b]fluoranthene $\mathrm{B}(\mathrm{b}) \mathrm{F}$ & 5 & 0.1 & $2 \mathrm{~B}$ & 17.60 & 0.02 & 163.38 \\
\hline Benzo[K]fluoranthene $\mathrm{B}(\mathrm{k}) \mathrm{F}$ & 5 & 0.1 & $2 \mathrm{~B}$ & 16.00 & 0.02 & 143.50 \\
\hline Benzo[a]pyrene (BaP) & 5 & 1 & 1 & 21.89 & 0.02 & 68.43 \\
\hline Dibenz(ah)anthracene (DahA) & 5 & 1 & $2 \mathrm{~A}$ & 0.18 & 0.02 & 1.12 \\
\hline Benzo[ghi]perylene (BghiP) & 6 & 0.01 & 3 & 0.10 & 0.02 & 0.92 \\
\hline Indeno(1, 2, 3cd)Pyrene (IcdP) & 6 & 0.1 & $2 \mathrm{~B}$ & 0.07 & 0.02 & 0.72 \\
\hline$\Sigma$ PAHs & & & & 878.82 & 0.32 & 4461.91 \\
\hline LMW PAHs & & & & 193.87 & 0.12 & 1459.81 \\
\hline HMW PAHs & & & & 684.95 & 0.20 & 3002.10 \\
\hline 2 Ring\% & & & & 2.85 & 0.15 & 17.70 \\
\hline 3 Ring\% & & & & 18.79 & 5.71 & 31.82 \\
\hline 4 Ring\% & & & & 65.09 & 23.15 & 84.97 \\
\hline 5, 6 Ring\% & & & & 13.26 & 1.79 & 56.41 \\
\hline TEQ & & & & 28.69 & 0.05 & 81.71 \\
\hline
\end{tabular}

$\Sigma$ PAHs: total PAH concentration. LMW PAHs: low molecular weight $2-3$ ring PAHs. HMWPAHs: high molecular weight 4 - 6 ring PAHs. TEF: PAHs toxic equivalency factor with respect to BaP [46] TEQ: Toxic equivalency concentration. Agents Classified by the International Agency Research of Cancer [47]: 1) Carcinogenic to humans; 2A) Probably carcinogenic to humans; 2B) Possibly carcinogenic to humans; 3) Not classifiable as to its carcinogenicity to humans. 
Ant, Flu, Pyr, and BghiP) in the soil samples of Sarcheshmeh Copper Plant were within the range of 0.16 to $450.02 \mu \mathrm{g} / \mathrm{kg}$ and 0.16 to $4118.41 \mu \mathrm{g} / \mathrm{kg}$, respectively. High $\Sigma$ PAHs concentrations were detected in samples S-6 (4461.91 $\mu \mathrm{g} / \mathrm{kg}), \mathrm{S}-5$ $(2737.20 \mu \mathrm{g} / \mathrm{kg})$, and S-2 $(1693.49 \mu \mathrm{g} / \mathrm{kg})$ at the central part of the study area where the smelters were located. Contrarily, $\Sigma \mathrm{PAH}$ lowest concentrations were found in the samples that were not directly affected by the industrial activities. These samples had been collected from the local upwind directions (stations 16, 17,18 , and 20 (background samples)). 16 PAHs have been reported to have the highest concentrations of $7220,37,000,22,200,8357,9200$, and $11,730 \mu \mathrm{g} / \mathrm{kg}$ in the soil profiles of Shanghai (China), South of Carolina (USA), Elizabeth River Wetland (USA), Mediterranean Coast (Egypt), north of Bohai, Yellow Seas (China), and Isfahan (Iran), respectively [19] [41] [42] [43] [44] [45]. The mean concentration of the total 16 PAHs in Sarcheshmeh Copper Plant was 878.82 $\mathrm{mg} \cdot \mathrm{kg}^{-1}$, which represented a low contamination compared to those reported from other industrial areas. A great deal of PAHs may be produced by many processes, such as sintering, coking, and steel-making as the main reasons for the high concentrations of PAHs in the environment.

Based on abundance, the compositions of PAHs in the surface soil samples at Kerman Sarcheshmeh Copper Smelter Plant consisted of 4 rings, 3 rings, 5 \& 6 rings, and 2 rings, respectively. The ring classes and percentages of PAHs for the 20 different sampling stations in the study area are shown in Figure 3.

The PAHs of High Molecular Weights (HMWs) (4 - 6 rings) were more abundant than those of low molecular weights ( 2 - 3 rings). The average percentage for the PAHs concentrations of HMWs (4 - 6 rings) was within the range of $51 \%$ and $93 \%$ compared to the total PAHs in the surface soil samples at Kerman

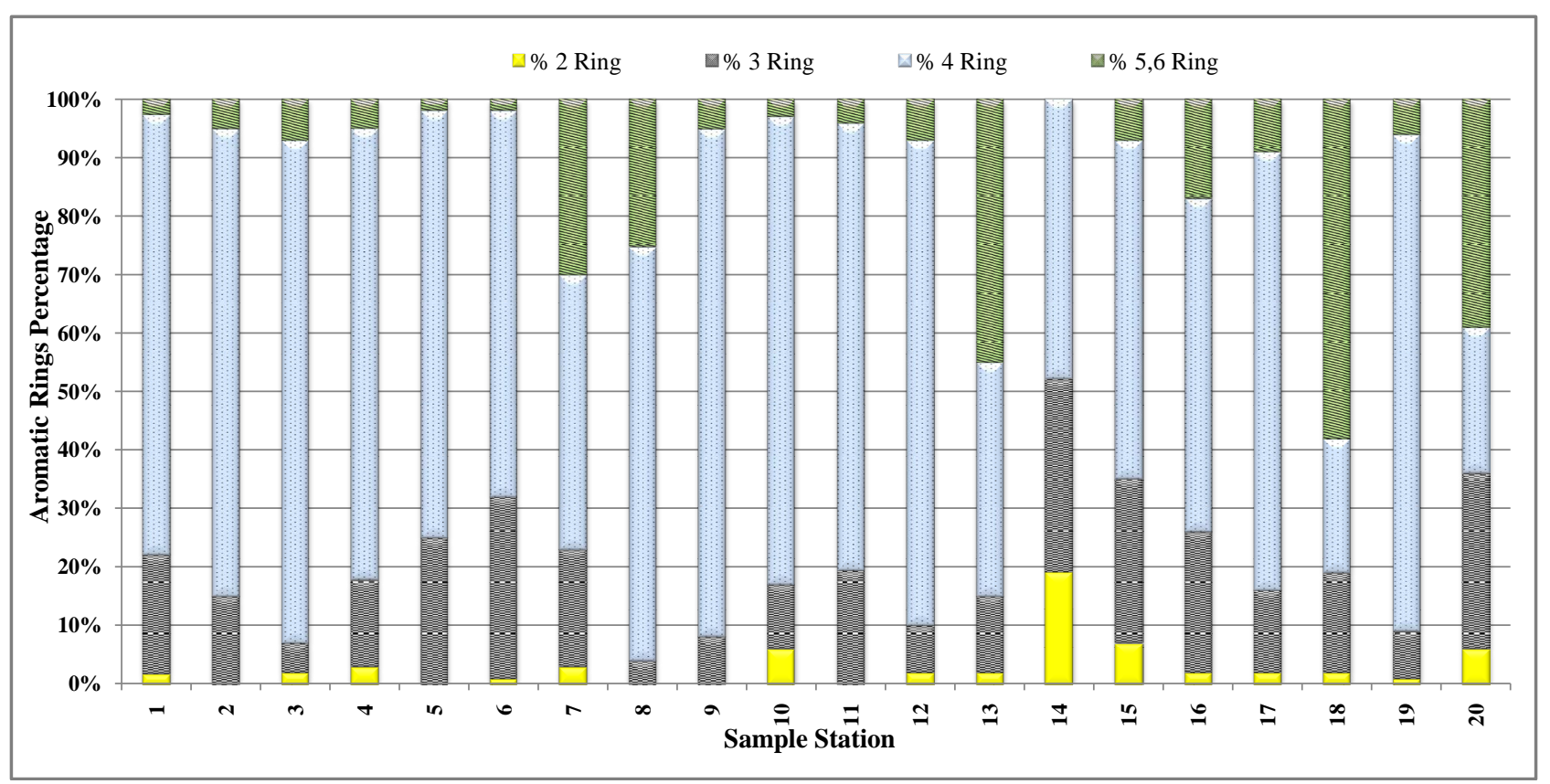

Figure 3. Percentages of the different rings in the total PAHs of the surface soil. 
Sarcheshmeh Copper Smelter Plant. The overall average percentage of PAHs concentrations of HMWs was found to be $78 \%$ in the surface soil samples.

The average percentage of PAHs concentrations of Low Molecular Weights (LMWs) (2 - 3 rings) was within the range of $7 \%$ and $49 \%$ compared to the total PAHs in the surface soil samples at Kerman Sarcheshmeh Copper Smelter Plant. The overall average percentage of PAHs concentrations of LMWs in the surface soil samples was found to be $21 \%$. Most of the surface soil samples at Kerman Sarcheshmeh Copper Smelter Plant were found to have similar compositions based on the percentages of rings. This can indicate their probable common sources [48]. Based on abundance, the highest rate of rings was related to the compositions of 4 rings, which can be a representative of industrial and traffic pollutions according to Wilcke and Amelung [49]. The high rates of abundance for the compositions of 3 rings and 4 rings associated with high PAH concentrations in the samples were indicative of their combined and common origins. The highest rate of concentration for the compositions of 2 rings was discovered in the surface soil samples S-6 and S-10 (soils from the stock and south part of the guard station at the smelter plant entrance). It is noteworthy that the compositions of 2 rings like Naphthalene are known for their volatility and vaporization after being replaced on the surface soil. Regarding the facts that S-6 was related to the dust of stock and PAH recently produced and S-10 to the south part of the guard station at the smelter plant entrance where many cars always existed, PAHs were continuously in the process of production. S-10 was in the direction of the dominant wind in the area, thus being greatly affected by the stock. Considering its distance from the stock, almost the first falling of the exit particles from the stock occurred in the sample station and consequently, the compositions of 2 rings produced in these 2 samples did not have sufficient time for evaporation, thus showing high concentrations of 2-ring compositions. PAHs have 2 to 6 benzene rings in cluster, linear, and angular arrangements. These compounds are classified into High Molecular Weight (HMW) and Low Molecular Weight (LMW) compounds containing 4 - 6 combined rings (e.g., dibenz $[\mathrm{a}, \mathrm{h}]$ anthracene) and 2 or 3 benzene rings (e.g. naphthalene), respectively [26] [50]. A significant harm to ecosystem inhabitants including humans and animals can be caused by several HMW PAHs via a chronic exposure [51]. In this research, the dominant 4-ring PAHs, which were believed to be essentially produced through the industrial pollutions [49], had a LMW/HMW ratio of $<1$ in most stations, thus indicating to be of similar pyrogenic sources.

\subsection{Source of PAHs}

To interpret the PAH sources, the following common aromatic diagnostic criteria were used: abundance ratio of 2- to 3-ring hydrocarbons to 4- to 6-ring hydrocarbons (LMW/HMW), Flu/(Flu + Pyr), Ant/(Ant + Phe $), \mathrm{BaA} /(\mathrm{Ba}+\mathrm{Chr})$, and $\mathrm{BaA} / \mathrm{Chr}$ [52] [53] [54]. The ratios of Flu/(Flu + Pyr), Ant/(Ant + Phe), and $\mathrm{BaA} /(\mathrm{BaA}+\mathrm{Chr})$ ranged within $0.23-0.53,1 \times 10^{-5}-0.77$, and $0.13-0.75$, respectively (Figure 4). 


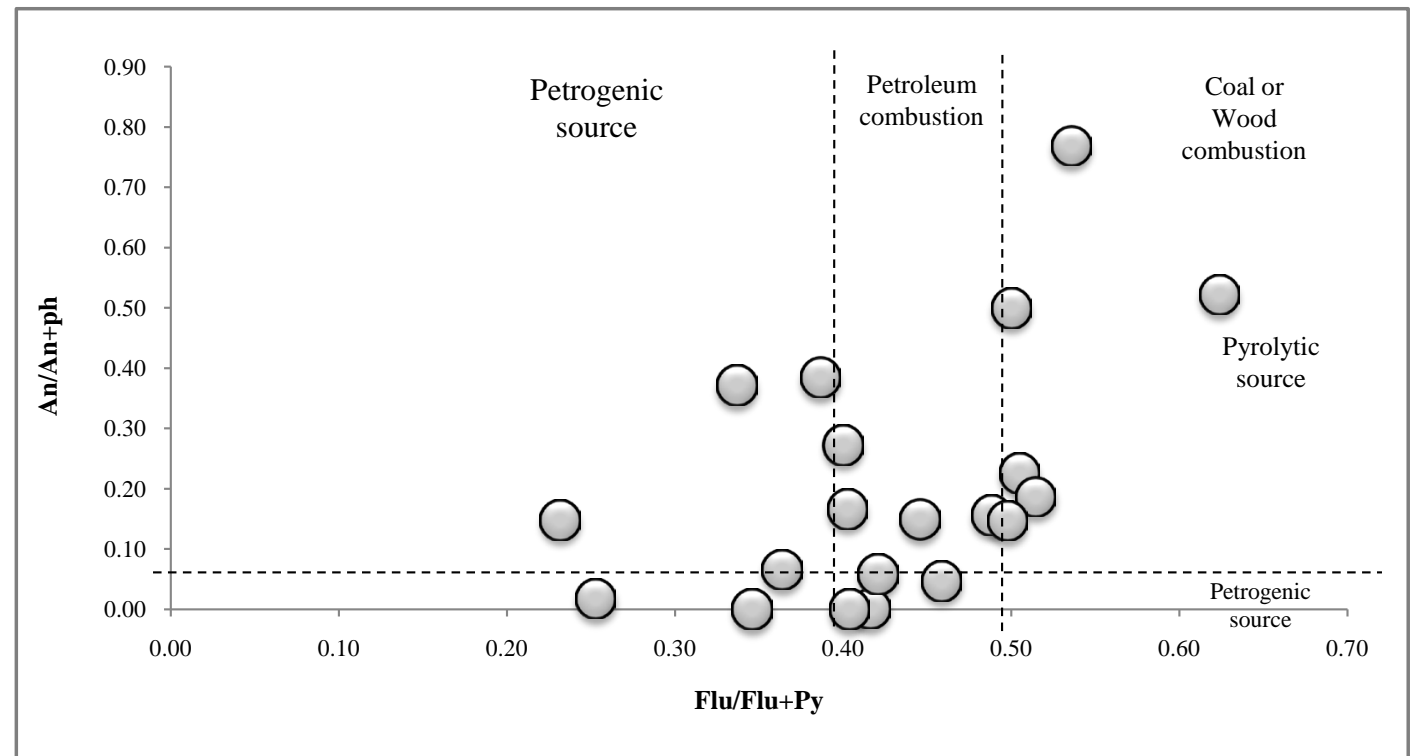

(a)

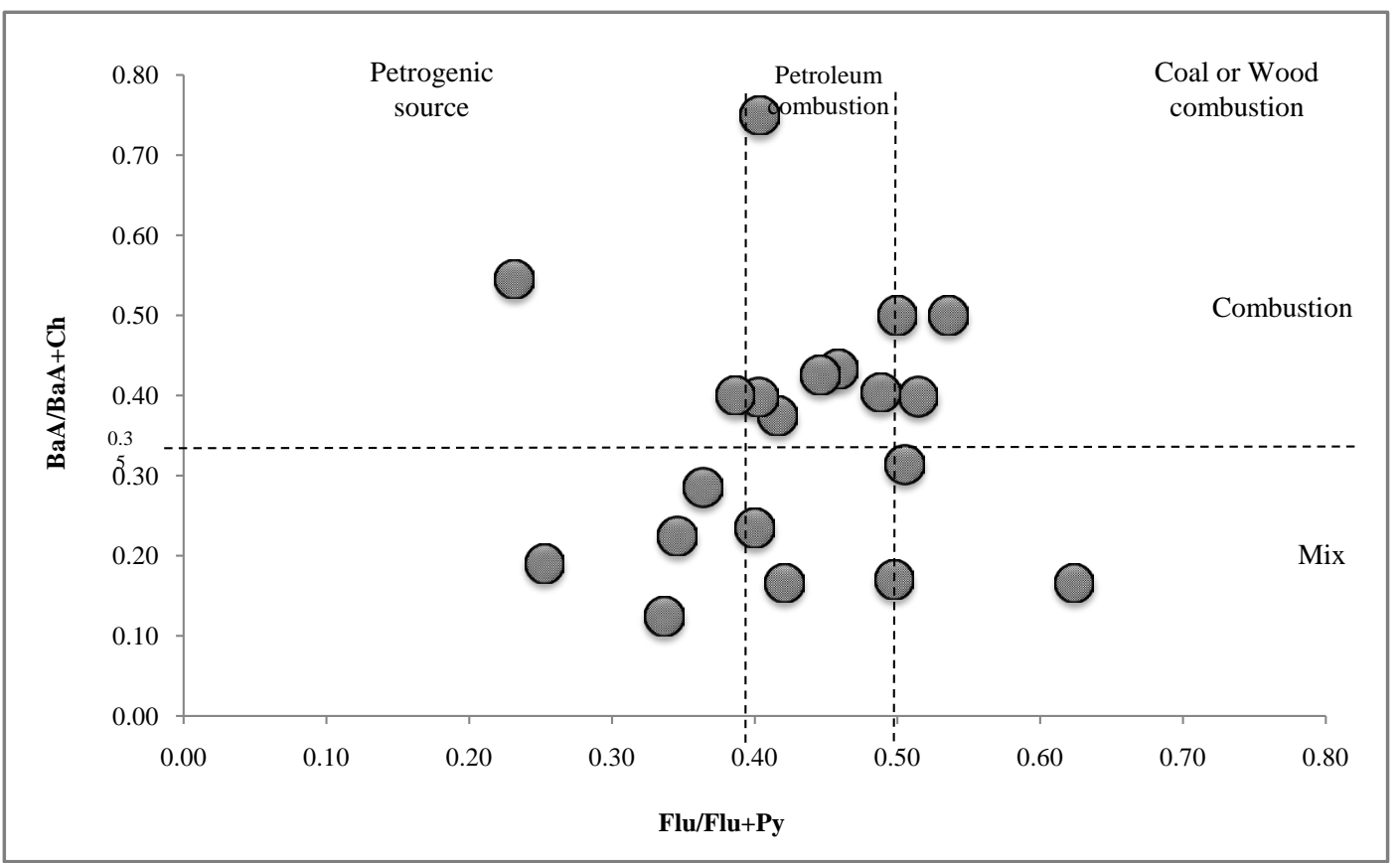

(b)

Figure 4. Cross-plots: (a) Flu/(Flu + Pyr) vs. Ant/(Ant + Phe); (b) Flu/(Flu + Pyr) vs. BaA/(BaA + Chr).

PAH mixed sources in the soil samples were mainly produced by the petroleum-based combustion products. The most common pyrolytic source of the PAHs in the study area was industrial activity. The average concentration of benzo(a)pyrene in Sarcheshmeh Copper Plant topsoil was $21.8 \mu \mathrm{g} / \mathrm{kg}$, thus being higher than the standard soil concentration. In addition to the activities of the copper smelter, the movements and activities of machines and vehicles at Sarcheshmeh Plant area enhanced burnings of oil compounds and thus, PAHs of petroleum combustion origin exited from vehicle exhausts were as a contamina- 
tion factor for Sarcheshmeh Plant surface soil, which was caused by polycyclic aromatic hydrocarbons. Oil derivatives splashed on the soil could be one of the factors for the distribution of polycyclic aromatic hydrocarbons. Therefore, in some parts of the plant associated with tremendous presence of vehicles and great sources of crude oil, high PAH values were found in the soil. Considering the fact that the whole area was affected by the exhaust flue, polycyclic aromatic hydrocarbons in the soil were of mixed sources (incomplete combustion of organic materials and crude oil or unburned oil and oil products).

\section{Conclusion}

There is a global legacy for the polluted soils contaminated by a variety of chemicals from a wide range of industries, such as steel smelting plants, electricity generators, oil refining factories, and mining sources. Soils are considered as "contaminated" when they have excessive amounts of an element or compound, which create a toxic response to biota that result in unacceptable risks to the environment or human health through a direct or indirect exposure. In this investigation, the concentrations, distributions, and probable sources of $16 \mathrm{PAHs}, 17$ dioxin/furans, and some heavy metals were detected in Sarcheshmeh Copper Smelter Plant. High levels of the mentioned compounds were found in the shortest distance from the smelter plant stock. Petroleum combustion products were found to have mainly produced PAHs in the soil samples. The major pyrolytic source for the PAHs in the study area was related to industrial activities. In comparison to the soil profiles of the different parts of the world, studied soil samples demonstrated a low-to-moderate contamination with heavy metals, $\mathrm{PCDD} / \mathrm{Fs}$, and PAHs through analysis.

\section{Acknowledgements}

The authors of this research would like to express their sincere acknowledgement to the staff members of Sarcheshmeh copper Plant in Kerman City both for helping us in the field work and providing a financial support.

\section{References}

[1] Kabata-Pendias, A. and Mukherjee, A.B. (2007) Trace Elements from Soil to Human. Springer Verlag, Berlin. https://doi.org/10.1007/978-3-540-32714-1

[2] Selinus, O. (2005) Essential of Medical Geology, Impacts of the Natural Environment of Public Health. Elsevier, Amsterdam.

[3] Lewis, M. and Pryor, R. (2013) Toxicities of Oil, Dispersants and Dispersed Oils to Algae and Aquatic Plants: Review and Database Value to Resource Sustainability. Environmental Pollution, 180, 345-367.

[4] Costa, A.S., Romão, L.P.C., Araújo, B.R., Lucas, S.C.O., Maciel, S.T.A., Wisniewski, A.J.R. and Alexandre, M.R. (2012) Environmental Strategies to Remove Volatile Aromatic Fractions (BTEX) from Petroleum Industry Wastewater Using Biomass. Bioresource Technology, 105, 31-39.

[5] Zhang, H.B., Luo, Y.M., Zhao, Q.G., Wong, M.H. and Zhang, G.L. (2006) Residues 
of Organochlorine Pesticides in Hong Kong Soils. Chemosphere, 63, 633-641.

[6] UN (United Nations) (2003) Economic and Social Council. Economic Commission for Europe. Health Risks of Persistent Organic Pollutants from Long-Range Transboundary Air Pollution. Section E.

[7] USEPA (1994) Health Assessment Document for 2, 3, 7, 8-Tertachlorodibenzo-pDioxin (TCDD) and Related Compounds. EPA/600/Bp-92/001c Estimating Exposure to Dioxin-Like Compounds, EPA/600/6-88/005cb. Office of Research and Development, Washington DC.

[8] Liu, L.B., Liu, Y., Lin, J.M., Tang, N., Hayakawa, K. and Maeda, T. (2007) Development of Analytical Methods for Polycyclic Aromatic Hydrocarbons (PAHs) in Airborne Particulates: A Review. Journal of Environmental Sciences, 19, 1-11.

[9] Motelay-Massei, A., Ollivon, D., Garban, B. and Chevreuil, M. (2003) Polycyclic Aromatic Hydrocarbons in Bulk Deposition at a Suburban Site: Assessment by Principal Component Analysis of the Influence of Meteorological Parameters. Atmospheric Environment, 37, 3135-3146.

[10] Stanimirova, I., Tauler, R. and Walczak, B. (2011) A Comparison of Positive Matrix Factorization and the Weighted Multivariate Curve Resolution Method. Application to Environmental Data. Environmental Science \& Technology, 45, 10102-10110. https://doi.org/10.1021/es201024m

[11] Kaya, E., Dumanoglu, Y., Kara, M., Altiok, H., Bayram, A., Elbir, T. and Odabasi, M. (2012) Spatial and Temporal Variation and Airesoil Exchange of Atmospheric PAHs and PCBs in an Industrial Region. Atmospheric Pollution Research, 3, 435449. https://doi.org/10.5094/APR.2012.050

[12] Sverdrup, L.E., Nielsen, T. and Krogh, P.H. (2002) Soil Ecotoxicity of Polycyclic Aromatic Hydrocarbons in Relation to Soil Sorption, Lipophilicity, and Water Solubility. Environmental Science \& Technology, 36, 2429-2435. https://doi.org/10.1021/es010180s

[13] Latimer, J. and Zheng, J. (2003) The Sources, Transport, and Fate of PAH in the Marine Environment. In: Douben, P.E.T., Ed., PAHs. An Ecotoxicological Perspective, John Wiley and Sons Ltd., New York. https://doi.org/10.1002/0470867132.ch2

[14] Baklanov, A., Hänninen, O., Slørdal, L.H., Kukkonen, J., Bjergene, N., Fay, B., et al. (2007) Integrated Systems for Forecasting Urban Meteorology, Air Pollution and Population Exposure. Atmospheric Chemistry and Physics, 7, 855-874. https://doi.org/10.5194/acp-7-855-2007

[15] Dickhut, R.M., Canuel, E.A., Gustafson, K.E., Liu, K., Arzayus, K.M., Walker, S.E., Edgecombe, G., Gaylor, M.O. and MacDonald, E.H. (2000) Automotive Sources of Carcinogenic Polycyclic Aromatic Hydrocarbons Associated with Particulate Matter in the Chesapeake Bay Region. Environmental Science and Technology, 34, 46354640. https://doi.org/10.1021/es000971e

[16] Larsen, R.K. and Baker, J.E. (2003) Source Apportionment of Polycyclic Aromatic Hydrocarbons in the Urban Atmosphere: A Comparison of Three Methods. Environmental Science \& Technology, 137, 1873-1881. https://doi.org/10.1021/es0206184

[17] Kameda, Y., Shirai, J., Komai, T., Nakanishi, J. and Masunaga, S. (2005) Atmospheric Polycyclic Aromatic Hydrocarbons: Size Distribution, Estimation of Their Risk and Their Depositions to the Human Respiratory Tract. Science of the Total Environment, 340, 71-80.

[18] Yu, Y., Guo, H., Liu, Y., Huang, K., Wang, Z. and Zhan, X. (2008) Mixed Uncertainty Analysis of Polycyclic Aromatic Hydrocarbon Inhalation and Risk Assess- 
ment in Ambient Air of Beijing. Journal of Environmental Sciences (China), 20, 505-512.

[19] Jiao, W., Wang, T., Khim, J.S., Luo, W., Hu, W., Naile, J.E., Giesy, J.P. and Lu, Y. (2013) Polycyclic Aromatic Hydrocarbons in Soils along the Coastal and Estuarine Areas of the Northern Bohai and Yellow Seas, China. Environmental Monitoring and Assessment, 185, 8185-8195. https://doi.org/10.1007/s10661-013-3166-7

[20] Yu, G., Zhang, Z., Yang, G., Zheng, W., Xu, L. and Cai, Z. (2014) Polycyclic Aromatic Hydrocarbons in Urban Soils of Hangzhou: Status, Distribution, Sources, and Potential Risk. Environmental Monitoring and Assessment, 186, 2775-2784. https://doi.org/10.1007/s10661-013-3578-4

[21] Tam, N.F.Y., Ke, L., Wang, X.H. and Wong, Y.S. (2001) Contamination of Polycyclic Aromatic Hydrocarbons in Surface Sediments of Mangrove Swamp. Environmental Pollution, 114, 255-263.

[22] Grova, N., Feidt, C., Crepineau, C., Laurent, C., Lafargue, P.E., Hachimi, A. and Rychen, G. (2002) Detection of Polycyclic Aromatic Hydrocarbon Levels in Milk Collected near Potential Contamination Sources. Food Chemistry, 50, 4640-4642. https://doi.org/10.1021/jf0201071

[23] Cardellicchio, N., Buccolieri, A., Giandomenico, S., Lerario, V.L., Lopez, L. and Pizzulli, F. (2006) Distribution and Occurrence of Polycyclic Aromatic Hydrocarbons (PAHs) in Sediments from the Mar Grande and Gulf of Taranto (Ionian Sea, Southern Italy). Annali di Chimica, 96, 51-64. https://doi.org/10.1002/adic.200690006

[24] Valavanidis, A., Vlachogianni, T., Triantafillaki, S., Dassenakis, M., Androutsos, F. and Scoullos, M. (2008) Polycyclic Aromatic Hydrocarbons in Surface Seawater and in Indigenous Mussel (Mytilusgalloprovincialis) from Coastal Areas of the Saronikos Gulf (Greece). Estuarine Coastal and Shelf Science, 79, 733-739.

[25] Cheney, M.A., Liu, J., Amei, A., Zhao, X., Joo, S.W. and Qian, S. (2009) A Comparative Study on the Uptake of Polycyclic Aromatic Hydrocarbons by Anodontacaliforniensis. Environmental Pollution, 157, 601-608.

[26] Abdollahi, S., Raoufi, Z., Faghiri, I., Savari, A., Nikpour, Y. and Manouri, A. (2013) Contamination Levels and Spatial Distributions of Heavy Metals and PAHs in Surface Sediment of Imam Khomeini Port, Persian Gulf, Iran. Marine Pollution Bulletin, 71, 336-345.

[27] Waterman, G.C. and Hamilton, R.L. (1975) The Sarcheshmeh Porphyry Copper, Deposit. Economic Geology, 70, 568-576.

https://doi.org/10.2113/gsecongeo.70.3.568

[28] Forster, H. (1978) Mesozoic-Cenozoic Metallogenesis in Iran. Journal of the Geological Society, 135, 443-455. https://doi.org/10.1144/gsigs.135.4.0443

[29] Shahabpour, J. and Kramers, J.D. (1987) Lead Isotope Data from the Sarcheshmeh Porphyry Copper Deposit, Iran. Mineralium Deposita, 22, 275-281. https://doi.org/10.1007/BF00204520

[30] CEN (1996) Stationary Source Emissions Determination of the Mass Concentration of PCDD/Fs. Reports EN 1996, 12-27.

[31] Van den Berg, M., Birnbaum, L., Bosveld, A.T., Brunstrom, B., Cook, P., Feeley, M., Giesy, J.P., Hanberg, A., Hasegawa, R., Kennedy, S.W., et al. (1998) Toxic Equivalency Factors (TEFs) for PCBs, PCDDs, PCDFs for Humans and Wildlife. Environmental Health Perspectives, 106, 775-792. https://doi.org/10.1289/ehp.98106775

[32] Ministry of Health (2012) Dioxins Fact Sheet. 
[33] Pierzynski, G.M., Sims, J.T. and Vance, G.F. (2000) Soils and Environmental Quality. CRC Press, London.

[34] Kabata-Pendias, A. and Pendias, H. (2001) Trace Metals in Soils and Plants. 2nd Edition, CRC Press, Boca Raton.

[35] D’Amore, J.J., Al-Abed, S.R., Scheckel, K.G. and Ryan, J.A. (2005) Methods for Speciation of Metals in Soils: A Review. Journal of Environmental Quality, 34, 17071745. https://doi.org/10.2134/jeq2004.0014

[36] Forster, H. and Jafarzadeh, A. (1994) The Bafq Mining District in Central Iran-A Highly Mineralized Infracambrian Volcanic Field. Economic Geology, 89, 16971721. https://doi.org/10.2113/gsecongeo.89.8.1697

[37] Moghtaderi, A., Moore, F. and Mohammadzadeh, A. (2007) The Application of Advanced Spaceborne Thermal Emission and Reflection (ASTER) Radiometer Data in the Detection of Alteration in the Chadormalupaleocrater, Bafq Region, Central Iran. Journal of Asian Earth Sciences, 30, 238-252.

[38] Pour, A.B. and Hashim, M. (2012) The Application of ASTER Remote Sensing Data to Porphyry Copper and Epithermal Gold Deposits. Ore Geology Reviews, 44, 1-9.

[39] Siegel, F.R. (2002) Environmental Geochemistry of Potentially Toxic Metals. Springer-Verlag, Berlin. https://doi.org/10.1007/978-3-662-04739-2

[40] European Commission, Joint Research Centre (2007) Derivation Methods of Soil Screening Values in Europe. A Review and Evaluation of National Procedures towards Harmonization. Editor Claudio Carlon. EUR 22805 EN.

[41] Kimbrough, K. and Dickhut, R. (2006) Assessment of Polycyclic Aromatic Hydrocarbon Input to Urban Wetlands in Relation to Adjacent Land Use. Marine Pollution Bulletin, 52, 1355-1363.

[42] Bu, Q.W., Zhang, Z.H., Lu, S. and He, F.P. (2009) Vertical Distribution and Environmental Significance of PAHs in Soil Profiles in Beijing, China. Environmental Geochemistry and Health, 31, 119-131. https://doi.org/10.1007/s10653-008-9171-z

[43] Barakat, A., Mostafa, O., Wade, A., et al. (2011) Distribution and Characteristics of PAHs in Sediments from the Mediterranean Coastal Environment of Egypt. Marine Pollution Bulletin, 62, 1969-1978.

[44] Wang, X.T., Miao, Y., Zhang, Y., Li, Y.C., Wu, M.H. and Yu, G. (2013) Polycyclic Aromatic Hydrocarbons (PAHs) in Urban Soils of the Megacity Shanghai: Occurrence, Source Apportionment and Potential Human Health Risk. Science of the Total Environment, 447, 80-89.

[45] Moore, F., Akhbarizadeh, R., Keshavarzi, B., Khabazi, S., Lahijanzadeh, A. and Kermani, M. (2015) Ecotoxicological Risk of Polycyclic Aromatic Hydrocarbons (PAHs) in Urban Soil of Isfahan Metropolis, Iran. Environmental Monitoring and Assessment, 187, 207-220. https://doi.org/10.1007/s10661-015-4433-6

[46] Nisbet, C. and LaGoy, P. (1992) Toxic Equivalency Factors (TEFs) for Polycyclic Aromatic Hydrocarbons (PAHs). Regulatory Toxicology and Pharmacology, 16, 290-300.

[47] IARC International Agency Research of Cancer (2011) Agents Classified by the IARC Monographs 1-102. 17 June 2011.

[48] Chung, M.K., Hu, R., Cheung, K.C. and Wong, M.H. (2007) Pollutants in Hong Kong Soils: Polycyclic Aromatic Hydrocarbons. Chemosphere, 67, 464-473.

[49] Wilcke, W. and Amelung, W. (2000) Persistent Organic Pollutants in Native Grassland Soils along a Climosequence in North America. Soil Science Society of America Journal, 64, 2140-2148. https://doi.org/10.2136/sssaj2000.6462140x 
[50] Tolosa, I., Mora, S.D., Sheikholeslami, M.R., Villeneuve, J.P., Bartocci, J. and Cattini, C. (2004) Aliphatic and Aromatic Hydrocarbons in Coastal Caspian Sea Sediments. Marine Pollution Bulletin, 48, 44-60.

[51] Saito, L., Rosen, M.R., Roesner, L. and Howard, N. (2010) Improving Estimates of Oil Pollution to the Sea from Landbased Sources. Marine Pollution Bulletin, 60, 990-997.

[52] Wang, W., Massey Simonich, M., Xue, M., Zhao, J., Zhang, N., Wang, R., Cao, J. and Tao, S. (2010) Concentrations, Sources and Spatial Distribution of Polycyclic Aromatic Hydrocarbons in Soils from Beijing, Tianjin and Surrounding Areas, North China. Environmental Pollution, 158, 1245-1251.

[53] Zhang, J., Cheng Yang, J., Wang, R., Hou, H., Du, X., Fan, S., Liu, J. and Dai, J. (2013) Effects of Pollution Sources and Soil Properties on Distribution of Polycyclic Aromatic Hydrocarbons and Risk Assessment. Science of Total Environment, 463 $464,1-10$.

[54] Kanzari, F., Syakti, A.D., Asia, L., Malleret, L., Piram, A., Mille, G. and Doumenq, P. (2014) Distributions and Sources of Persistent Organic Pollutants (Aliphatic Hydrocarbons, PAHs, PCBs and Pesticides) in Surface Sediments of an Industrialized Urban River (Huveaune), France. Science of the Total Environment, 478, 141-151.

Submit or recommend next manuscript to SCIRP and we will provide best service for you:

Accepting pre-submission inquiries through Email, Facebook, LinkedIn, Twitter, etc. A wide selection of journals (inclusive of 9 subjects, more than 200 journals)

Providing 24-hour high-quality service

User-friendly online submission system

Fair and swift peer-review system

Efficient typesetting and proofreading procedure

Display of the result of downloads and visits, as well as the number of cited articles

Maximum dissemination of your research work

Submit your manuscript at: http://papersubmission.scirp.org/

Or contact gep@scirp.org 